\title{
Bank Competition, Efficiency and Stability in Macau
}

\author{
Hui (Harry) Xia ${ }^{1}$, Kevin Lei $^{2} \&$ Jiaochen Liang ${ }^{1}$ \\ ${ }^{1}$ California State University, Fresno, USA \\ ${ }^{2}$ University of Saint Joseph, Macau \\ Correspondence: Hui (Harry) Xia, Craig School of Business, California State University, Fresno, CA 93740, USA. \\ E-mail: hxia@csufresno.edu
}

Received: September 30, 2019

Accepted: October 29, $2019 \quad$ Online Published: November 4, 2019

doi:10.5430/afr.v8n4p157

URL: https://doi.org/10.5430/afr.v8n4p157

\begin{abstract}
Macau has the uppermost population density and the fourth-highest GDP per capita in the world. Macau's banking system is regarded as one of the most important indicators of Macau's economic growth during its transformation into a wealthy and modern metropolis, which calls for thorough research to explore the relationship of bank competition, efficiency and stability in Macau. In this study, we use a sample of 26 Macau banks from its return to China in 1999 to 2016 to determine that bank competition does cause efficiency in Macau over the period. We also find indications of a positive but not significant connection between bank market power and bank fragility including income volatility and insolvency risk. Moreover, this study finds no evidence that the size of operations proxied by total bank loans and total assets would impact bank efficiency, indicating that economies of scale or bank market share don't necessarily bring about efficiency in Macau. Our evidence contributes to the literature by being the first to thoroughly examine and ascertain the relation of bank competition, efficiency and stability in Macau. The findings provide meaningful implications to the practitioners and policymakers to make sound decisions accordingly, especially to closely monitor and maintain a proper level of competition in Macau's banking sector.
\end{abstract}

JEL classification: F33, G21, L11

Keywords: banking competition, market structure, efficiency, financial stability, Macau banks

\section{Introduction}

The word "Finance" can be translated as "the circulation or movement of money" in Chinese. If you want to witness a really spectacular view of cash flow, you should pay a visit to Macau, China. Many call Macau the Las Vegas of Asia. It has been ranked as the world's largest gambling center since 2006 (Sheldon, 2015) and Macau's gross gaming revenue reached around four times as high as that of Las Vegas in 2016. Between 1999 and 2016, Macau's Gross Domestic Product (GDP) increased by an annualized growth rate of $12 \%$ and soared from Macanese Pataca (MOP) 52 billion (USD 6.5 billion) to MOP 362 billion (USD 45.1 billion), Macau's GDP per capita reached MOP 560913 (USD 70 160), (Note 1) among the wealthiest in the world, ranking the $4^{\text {th }}$ globally just behind Luxembourg, Switzerland, and Norway, in 2016. (Note 2) In addition to its fast pace of economic growth, Macau also successfully maintains a very low unemployment rate, a decent level of social welfare, and a high life expectancy (Sheng \& Gu, 2018).

Originally known as Portuguese Macau, it was controlled by the Portuguese empire beginning in the 1500s until Macau's handover to China on December 20, 1999 (Sheldon, 2015). Macau has managed to keep its status as an independent economic region since its return to China. It preserves the free market system and adopts a free trade policy for continued development. The World Trade Organization evaluated Macau in 2002 and 2007 and recognized Macau as one of the most open regions in the world. In terms of Index of Economic Freedom, Macau was ranked $9^{\text {th }}$ in the Asia-Pacific region and $37^{\text {th }}$ out of 178 economies worldwide in 2016. (Note 3)

Upon its return to China in 1999, Macau's four pillar sectors were manufacturing, construction and real estate, financial services, and gaming (Sheng \& Gu, 2018). Banks, including the ones in Macau, play an essential role in providing financial services to firms and households (The World Bank, 2018). The extant literature posits that banks issue transaction accounts; provide the backup source of liquidity to all other institutions, financial and nonfinancial; and act as the transmission belt for monetary policy. Banks must be competitively viable and efficient in order to preserve essential bank functions (Corrigan 1982). Moreover, banks reduce information asymmetry between 
borrowers and lenders by monitoring and screening debtors to minimize moral hazard and adverse selection problems (Hughes \& Mester, 2013). Banks serve as a critical component of the payment system whose activities directly or indirectly impact economic stability, and any bank failure can result in systemic crisis (Fethi \& Pasiouras, 2009).

Macau's banking industry had enjoyed rapid growth along with the local economy from 1999 to 2016. The bank operations indicated by bank total assets which grew from MOP 139 billion to MOP 1390 billion, total net loans from MOP 42 billion to MOP 783 billion and interest income from MOP 8 billion to MOP 30 billion, were highly correlated to Macau's GDP growth (with the correlation coefficient of $2.976^{* * *}, 1.802^{* * *}$, and $0.061^{* * *}$, respectively, untabulated) (Note 4) during this time period. Such correlation provides evidence of a solid connection between Macau's banking system and its economic growth during Macau's transformation into a wealthy and modern metropolis. However, the size of 26 banks in Macau and their market shares varied significantly in terms of total assets and total loans. As of 2016, the top three banks in Macau, Bank of China (BOC), Industrial and Commercial Bank of China in Macau (C-ICBC) and Tai Fung Bank (TaiFung), a BOC affiliate were subsidiaries of banks located in Mainland China. Together, they dominated the banking market in Macau with more than 65\% share of total loans and total bank assets.

So far, there has been no in-depth research on Macau's banking system, which performs the essential functions in its fast growth since 1999 leading to one of the wealthiest economies globally. Due to the strong connection to economic growth and relatively high market concentration, it is time for a thorough study of Macau's banking sector with a focus on the key linkage related to bank competition, efficiency, and stability.

To the best of our knowledge, we are the first to use a sample of 26 banks, which covers all the banks with normal operations in Macau from its return to China in 1999 to 2016, to conduct a comprehensive review of Macau's banking system. By using the Lerner index and the Herfindahl-Hirschman Index (HHI) indicating bank competition and Distribution Free Approach (DFA) measuring bank efficiency, through the Granger causality test, we demonstrate that bank competition does Granger cause efficiency in Macau over the period. Our findings also indicate a positive but not significant connection between bank competition and stability. More specifically, bank market power proxied by the Lerner index has an insignificantly positive connection to bank fragility including income volatility and insolvency risk, which echoes the direction of the competition-stability theory in Macau, though the results are statistically insignificant. Furthermore, our analysis finds an insignificantly negative linkage between bank size proxied by the rank of total loan and total assets, and bank efficiency, which indicates that economies of scale or market share don't necessarily bring about efficiency in Macau's banking industry.

Our findings not only contribute to the literature but also provide sound implications to the practitioners and policymakers. This research provides robust empirical evidence that bank competition causes efficiency in Macau. The growing market concentration may eventually change the landscape of the bank competition and negatively affect bank efficiency in Macau. Therefore, bank competition should be a key observation constantly under the scrutiny of policymakers in Macau. Our results also suggest a potential linkage between high market power and high bank income volatility and insolvency risk. Therefore, based on the relatively high level of market concentration demonstrated by both the market share and the Lerner index in this research, one possible suggestion to the policymakers is to consider specific antitrust measures to discourage the growing market power of top players in the banking sector.

Furthermore, based on our findings that bank size doesn't necessarily result in economies of scale in Macau's banking industry, it becomes a meaningful task for large banks with low efficiency to benchmark against the small but high-efficiency counterparts to benefit from their best practices. The large banks may learn from the small banks like WH and First Commercial Bank to streamline their operations to improve their efficiency. After all, a more competitive and efficient banking industry would bring more low-cost financial resources to Macau's economy and better support its future growth.

The remainder of this study is organized as follows: Section 2 provides a review of literature and research proposition development; Section 3 describes the sample data and research design; Section 4 presents the analysis of the results; and Section 5 offers the conclusions and directions for future research.

\section{Literature Review and Research Propositions}

\subsection{Bank Competition and Efficiency}

The recent global financial and economic crisis has highlighted the crucial position of banks in the economy. Banks play a critical role in the payment system, the provision of credit (Beck, Demirgüç-Kunt, \& Maksimovic, 2004), the 
transmission of monetary policy, overall industrial and economic growth (Claessens \& Laeven, 2005), and maintaining financial stability (Boyd \& De Nicoló, 2005; Boyd, De Nicoló, \& Smith, 2004). The essential role of banks in the economy makes the issue of banking competition extremely important (Bikker, Shaffer, \& Spierdijk, 2012).

The majority of the literature studies about bank competition conclude that banks operate in monopolistic competitive environments (Beck, Demirgüç-Kunt, \& Levine, 2006; Claessens \& Laeven, 2004). Bank competition indicators can be categorized into two groups: structural and conduct indicators (Dubovik \& Kalara, 2018). The Structure-Conduct Performance (SCP) paradigm uses the structure of the market to determine the conduct of the firms affecting their performance and argues that concentration measures serve as proxies for the level of competition (Bain, 1956). The advantage of using SCP approach, e.g., HHI, is that concentration measures are relatively easy to observe without requiring data on the prices and costs of firms. However, it receives criticism through the theory of the contestable markets, which argues that, if the costs of entry and exit are low, even a highly concentrated market can be competitive (Baumol, Panzar, \& Willig, 1983). Contrary to SCP, the New Empirical Industrial Organization suggests that competition can be directly captured through the conduct assessment of firms through demand elasticities or market dynamics (Bresnahan, 1989). Popular conduct measures of competition include the Lerner index, the Panzar and Rosse H-statistic (Panzar \& Rosse, 1987), and the Boone indicator (Boone, 2008). While the H-statistic and Boone indicator summarize only the total activities of banks, descriptive statistics like HHI and the Lerner index, to a certain extent, being robust measures of competition at the individual bank level, are widely used in the banking industry among others by the European Commission (Dubovik \& Kalara, 2018). In this study, we choose the Lerner index to measure bank competition and HHI for the robustness check.

Some studies find that bank competitive conditions have deteriorated on average during the 2000s, while market power further grew after the financial crisis years (Beck, De Jonghe, \& Schepens, 2013; Clerides, Delis, \& Kokas, 2015). Nevertheless, the empirical results are differentiated across the region and market groups. Apergis (2015) identifies evidence in favor of monopolistic competition and decline competition after the recent financial crisis in the banking sectors of emerging market economies spanning the period of 2000 to 2012. Staikouras and Koutsomanoli-Fillipaki (2006) conduct a multi-country analysis for the EU right after the enlargement to 25 member countries and find evidence of larger banks performing more competitively and with new banking members demonstrating higher levels of competition. However, using the Lerner index over the period of 2002 to 2011, Fungáčová, Pessarossi and Weill (2013) observe no increase in bank competition in China. Due to the strong connection between Macau's economic growth and its banking sector, it is meaningful to study the competitive condition of banks in Macau and how it evolves after 1999.

Besides bank competition, another critical aspect of the banking industry is bank performance or efficiency. It is crucial to improve bank performance by identifying reasons for inefficient resource allocation and encouraging the best practices. Bank performance is usually evaluated through frontier efficiency analysis, which benchmarks the efficiency of banks with the best performing ones in the sector and then results can be employed for further analysis and best practices sharing (Bhatia, Basu, Mitra, \& Dash, 2018). Frontier efficiency, which overcomes the shortcoming of the ratio and regression analysis through benchmarking techniques comparing the performance with the peers on scale, revenue, cost, profit and technology utilization (Banker, Cummins, \& Klumpes, 2010). The results gained from efficiency analysis can help management to pinpoint the opportunity areas where the bank is underperforming in comparison to its competitors to set future directions for improvement. The frontier efficiency methodology includes non-parametric and parametric approaches. Non-parametric approaches typically include Data Envelopment Analysis (DEA) and Free Disposal Hull (FDH) analysis. Parametric techniques normally include Stochastic Frontier Approach (SFA) and DFA (Bhatia et al., 2018).

Non-parametric approaches are not restrictive regarding functional form specification and the distribution of the random error. DEA focuses on decision-making units (DMUs), which convert a given amount of inputs to specific output (Charnes, Cooper, \& Rhodes, 1978). These DMUs don't assume a particular functional form/shape for the frontier in the conversion process of inputs to outputs and envelop the observations under a frontier. DEA is flexible and allows for various assumptions regarding returns to scale and input- or output-oriented model. However, DEA does not allow for random error. Any deviation from the frontier in DEA would be treated as inefficiency which may lead to overstatement (Berger \& Mester, 1997). As a modified version of DEA, FDH estimator is introduced to relax the convexity assumption of DEA (Deprins, Simar, \& Tulkens, 1984). Another measure stemmed from DEA is the Malmquist index which evaluates the efficiency change over time (Tone, 2004). However, all nonparametric approaches are sensitive to extreme values and don’t allow for noisy data (Simar \& Wilson, 2013). 
Parametric approaches do not suffer from the drawback of non-parametric methods. Instead, they proceed with assumed specific functional form and the distribution of random error. SFA is applied as an econometric frontier approach to the bank performance analysis, in which inefficiencies are assumed to strictly follow half-normal (asymmetric) and random errors are expected to follow standard normal (symmetric) distribution (Ferrier \& Lovell, 1990). DFA is another parametric frontier technique to address the criticism of SFA's arbitrary and strict assumptions. DFA relaxes distributional assumptions and assumes inefficiencies to be stable over time. It treats the expected value of random error to be zero, over a period of time. We select DFA to measure bank efficiency in this study.

It is important for policymakers to identify the competition-efficiency relationship in their market and set suitable guidelines accordingly. Theoretically, the competition-efficiency relationship can be grouped along two dimensions: causation and direction (Koetter, Kolari, \& Spierdijk, 2008). Starting from causation, the efficient structure hypothesis posits that bank efficiency determines the market structure. Peltzman (1977) argues that concentration actually signals efficiency rather than collusion. The most efficient banks possess a long-run competitive advantage and acquire market shares which leads to more market power and higher market concentration (De Jonghe \& Vennet, 2008; Demsetz, 1973).

In contrast, the market structure, structure-performance, and competition-efficiency hypotheses posit a reverse causality to assume that the bank's market power determines efficiency. Among them, the "quiet life" hypothesis argues that, when market power prevails, bank managers may not have incentives to work diligently to lower the costs and maximize the profits, thereby reducing cost efficiency, namely, a quiet life (Berger \& Hannan, 1998). Delis and Tsionas (2009) use a sample of European banks to provide empirical evidence on the analysis of efficiency and market power and report a negative relationship between market power and efficiency, in line with the predictions of the "quiet life" hypothesis.

In terms of direction, the "quiet life" hypothesis is not always supported by the empirical findings. Maudos and de Guevara (2007) find a positive relationship between bank market power and cost efficiency in EU-15 countries over from 1993 to 2002, which rejects the "quiet life" hypothesis. Employing an industrial organization-based approach to large data sets for European and U.S. banks, Schaeck and Čihák (2008) use Granger causality tests to establish the link between bank competition and profit efficiency measures, and demonstrate that high competition (or lower market power) does indeed increase bank efficiency. A later study on the evolution and convergence of competition in 27 banking systems of European Union for the period of 2004 to 2010 confirms the competition-efficiency hypothesis in terms of cost and profit efficiency, which states that an increase in banking competition levels would bring an increase in the efficiency level of banks (Andrieş \& Căpraru, 2014).

Furthermore, there is ambiguous or even contradictory evidence on the competition-efficiency relationship. Using a sample of European banks, Casu and Girardone (2006) do not determine a clear connection between efficiency and competition. A similar study finds no significant relationship between bank competition and efficiency in China (Fungáčová et al., 2013), which is supported by Tan (2016) who uses the Lerner index as a competition measure to test its impact on bank profitability and finds no robust effect of competition on Chinese bank profitability. A more recent study of the Chinese banking industry indicates that higher competition leads to lower profitability, where the structure-performance hypothesis holds better than the efficient structure paradigm (Tan, Floros, \& Anchor, 2017). However, Koetter, Kolari, and Spierdijk (2008) posit that competition and efficiency are intertwined. They use a structural model to find support for the efficient structure hypothesis rather than the "quiet life" hypothesis for the U.S. banks.

Although Macau banks' size, deposit and loan business, and non-interest income have grown at an average rate of 10\% (Gong \& Lin, 2011) and banks have been playing an essential role in Macau's impressive economic growth since its return to China, there are only a few empirical studies on the banking efficiency in Macau. Mendes and Rebelo (2000) use the classic Malmquist index to measure the productivity changes of 17 banks in Macau from 1990 to 1997. Fu and Vong (2011) use DEA approach to find that the operations of banks in Hong Kong and Macau maintain high technical efficiency of over $97 \%$. They also argue that banks in Macau are slightly more efficient and more sensitive to macroeconomic changes than their counterparts in Hong Kong over the period of 1995 to 2006. This study only involves a limited number of large commercial banks in Macau and, by using DEA method, excludes the impacts caused by random errors in efficiency assessment. Another research conducted by Gong and Lin (2011) uses the Bootstrap DEA model and the Malmquist index to evaluate the operational efficiency of the banking industry in Macau from 2001 to 2008 and explores the impact of capital adequacy ratio, loan-to-deposit ratio, asset size, non-interest revenue ratio, market power, economic growth, inflation rate and real interest rate on efficiency scores. They conclude that the loan-to-deposit ratio has a positive effect on the efficiency of Macau banks. On the contrary, 
the scale of banks, non-interest business, and efficiency are negatively correlated. The productivity of the banking industry, which is closely linked to the fluctuations in the economy of Macau, makes no significant improvement from 2001 to 2008 (Gong \& Lin, 2011). However, there has been no in-depth research on the relationship between bank competition and efficiency in Macau.

It is clear that the inconclusive evidence on bank competition-efficiency relationship in other markets and the lack of thorough exploration in Macau lead to our first research proposition to examine the causation between bank efficiency and competition in Macau with the following hypotheses:

H1: The null hypothesis is "competition does not Granger cause efficiency," and the alternative hypothesis is "competition does Granger cause efficiency."

H2: The null hypothesis is "efficiency does not Granger cause competition," and the alternative hypothesis is "efficiency does Granger cause competition."

\subsection{Bank Competition and Bank Stability}

Banks form a part of the payment system, and consequently, banking activities directly or indirectly affect economic stability. Any bank failure can cause a systemic crisis (Fethi \& Pasiouras, 2009). One focus of the existing literature is on the relationship between bank competition and bank stability as the center of banking sector policy debate among academics and policymakers (Diallo, 2015).

There are two strands of the literature, namely the "competition-stability" and the "competition-fragility" views. According to the competition-stability theory, banks with greater market power result in higher bank risk due to the higher interest rates charged to loan customers which would increase loan portfolio risk and intensify moral hazard and adverse selection problems. Monopolistic banks charge higher loan rates, which may induce borrowers to take on risky investments resulting in the potential increase of loan defaults and causing a higher probability of bank failure (Boyd \& De Nicoló, 2005). Furthermore, larger banks are often more likely to have deposit insurance and the government's safety net so that they are inefficiently managed and more likely to fail. With the protection provided by public guarantees, large bank managers may take on risky investments. Mishkin (1999) suggests the so-called 'too-big-to-fail' concept and argues that, along with the size of banks, the moral hazard problem becomes more severe. The competition-stability hypothesis is supported by empirical evidence from the banks in the U.S. (De Nicolo, Jalal, \& Boyd, 2006), European (Schaeck \& Čihák, 2014; Uhde \& Heimeshoff, 2009) and 55 emerging and developing countries (Amidu \& Wolfe, 2013). In summary, the less competition, the more risk.

Under the alternative competition-fragility theory, banks with greater market power also have less overall risk exposure. More competition erodes banks' market power, reduces profitability, and causes decreased franchise value and induces banks' risk-taking (Berger, Klapper, \& Turk-Ariss, 2009). The charter value hypothesis (Keeley, 1990) or franchise value hypothesis provides banks with a valuable source of monopoly power (Hellmann, Murdock, \& Stiglitz, 2000). Higher franchise value is expected to reduce risk-taking incentives and increase capital due to the growing opportunity costs when bankruptcy occurs. In other words, the less competition, the less risk. Banks in the U.S. with high charter value operate more safely who hold more capital and take on less portfolio risk, mainly through diversifying their lending activities (Demsetz, Saidenberg, \& Strahan, 1996). Studying data on 69 countries from 1980 to 1997, Beck et al. (2006) find that crises are less likely in economies with more market concentration in banking systems. The competition-fragility theory is also supported by empirical evidence from Spain (Saurina Salas, Jiménez, \& Lopez, 2007) and Latin American countries (Yeyati \& Micco, 2007). Furthermore, an increase in competition will have a larger impact on banks' fragility in countries with stricter activity restrictions, lower systemic fragility, more generous deposit insurance better-developed stock exchanges, and more effective systems of credit information sharing (Beck et al., 2013).

The existing literature also provides disputable results. Banking data from Gulf Cooperation Council (GCC) market support for both competition-stability and competition-fragility views in the area (Saif-Alyousfi, Saha, \& Md-Rus, 2018). Intensified competition decreases insolvency risk and credit risk but increases liquidity risk in the Chinese banking industry (Tan \& Floros, 2018). Martinez-Miera and Repullo (2010) suggest a nonlinear relationship between competition and bank risk-taking who propose a U-shaped relationship between bank competition and bank failure risk. Again, there has been no research on the relationship between bank competition and stability in Macau.

The relationship between bank competition and stability remains a widely debated issue. Meanwhile, it is also an unexplored area in Macau, which leads to our second research proposition to examine the association between bank competition and stability with the null hypothesis that "bank competition does not impact bank stability in Macau" (H3). 


\subsection{The Effect of Bank Size on Efficiency}

Another argument on bank efficiency is related to bank size. In microeconomics, economies of scale mean the cost advantages that companies manage to gain due to the growth of their scale of operation, or simply say that firms can do things more efficiently with increasing size (Chandler, 1977). There are studies of banks in different markets that provide support to a positive effect of bank size on efficiency. Without risk and quality factors, inefficiency decreases with the growth of bank size in Japan (Altunbas, Liu, Molyneux, \& Seth, 2000). Similar findings are available in the European banking systems (Cavallo \& Rossi, 2002; Lang \& Welzel, 1996), Latin American countries (Carvallo \& Kasman, 2005), and Asian countries like India, Bangladesh, Pakistan and Sri Lanka (Perera, Skully, \& Wickramanayake, 2007).

However, there are contradictory results arguing that bank size is positively related to inefficiency. Large banks, particularly in separated banking countries, show significant diseconomies of scale (Allen \& Rai, 1996). Similar empirical evidence is found in the Chinese banking sector by examination of bank ownership and size (Kumbhakar \& Wang, 2007). Additional support from 10 of the European Union countries shows that, for medium-size and huge banks, bank size is negatively related to cost and profit efficiency (Maudos, Pastor, Pérez, \& Quesada, 2002).

Moreover, there are mixed results regarding the relationship between bank size and banking efficiency presented in the extant literature. Some argue that such a tie varies depending on bank size by category. Large banks show significant inefficiency while small ones show significant scale economies in the Ukrainian banking sector (Mertens \& Urga, 2001). Others find that the large state-owned banks and smaller banks are more efficient than medium-sized banks in China (Chen, Skully, \& Brown, 2005). Using the case of Italian banks, researchers find that there is no clear relationship between asset size and bank efficiency (Girardone, Molyneux, \& Gardener, 2004). The examination of the cost efficiency of the U.S. banks by employing both parametric and non-parametric frontier techniques finds no indication that large banks are more cost efficient than small banks (Ferrier \& Lovell, 1990).

The debate on bank size and efficiency is still unsettled. Furthermore, there is no prior research related to the effect of bank size on efficiency in Macau, which leads to our third research proposition to explore the relationship between bank size and bank efficiency with the null hypothesis that "bank size has no impact on bank efficiency in Macau" (H4).

\section{Sample and Research Design}

\subsection{Data}

The sample data are retrieved from the annual financial statements of the banks in Macau over the period of 1999 to 2016 available through AMCM's website. AMCM requires every bank in Macau to provide its annual financial statements, including the balance sheet and income statement, then releases such information through its website to the public. At present, there are 29 banks in Macau, of which 10 are locally incorporated (including the Postal Savings Office), and 19 are branches of overseas banks. The sample used in this research consists of 26 banks in Macau with 388 firm-year observations in total (some banks started their operations after 1999). Postal Savings Office; Banco Delta Asia (BDA) which was designated by the U.S. Department of the Treasury as primary money laundering concern under the USA PATRIOT ACT and sanctioned as complicit in a North Korean illegal activity in September 2005; and Agricultural Bank of China which just opened its Macau branch in the second half of 2017, are excluded in this research. Therefore, the sample used in this research covers all the banks with normal operations in Macau from 1999 to 2016.

\subsection{Bank Competition}

In this study, we use conduct indicator of the Lerner index to measure bank competition in Macau and structural indicator of HHI in the robustness check. The Lerner index, formalized by Abba Lerner in 1934, is widely used in the banking industry (Berger et al., 2009). It estimates the market structure by measuring the strength of monopoly power. The Lerner index quantifies the markup of price over marginal cost, indicating the bank's ability to set the price above its marginal cost. The index (Lerner or COM) ranges from a high of 1 to a low of 0 . In a perfectly competitive market, the set price is supposed to be equal to its marginal cost $(\mathrm{P}=\mathrm{MC})$ and therefore, Lerner=0, such a bank will have no market power. A greater index means higher market power or lower competition. It serves as an inverse measure of competition. The Lerner index, according to Berger et al. (2009), measures competition of each period at the bank level can be calculated as:

$$
\text { Lerner or } C O M=\frac{(\mathrm{P}-\mathrm{MC})}{\mathrm{P}}
$$

where $\mathrm{P}$ is the price of the bank. In the banking industry, interest revenues from loans dominate the performance of 
each bank. The price is computed as interest income divided by net loans, which are total loans minus non-performing loans. Following the existing literature (Fernandez de Guevara \& Maudos, 2009; Tai, 2012), a translog function is constructed to find out the marginal cost of each bank (MC) by including three inputs prices (labor, physical capital, and borrowed funds) and one output value (loans). We use the following translog cost function as:

$$
\ln \mathrm{TC}=\alpha_{0}+\alpha_{1} \ln \mathrm{y}+\frac{1}{2} \alpha_{2}(\ln \mathrm{y})^{2}+\sum_{\mathrm{j}=1}^{3} \beta_{\mathrm{j}} \ln \mathrm{w}_{\mathrm{j}}+\sum_{\mathrm{j}=1}^{3} \sum_{\mathrm{k}=1}^{3} \beta_{\mathrm{jk}} \ln \mathrm{w}_{\mathrm{j}} \ln \mathrm{w}_{\mathrm{k}}+\sum_{\mathrm{j}=1}^{3} \gamma_{\mathrm{j}} \ln \mathrm{y} \ln \mathrm{w}_{\mathrm{j}}+\varepsilon
$$

where the price of output (y) is measured by loans, and input prices for labor, physical capital, borrowed funds are computed by the ratio of personnel expenses to total assets $\left(\mathrm{w}_{1}\right)$, depreciation expenses for physical capital to fixed assets $\left(\mathrm{w}_{2}\right)$, and interest expense to borrowed funds $\left(\mathrm{w}_{3}\right)$. Total Costs (TC) is the sum of $\mathrm{w}_{1}, \mathrm{w}_{2}$ and $\mathrm{w}_{3}$. Therefore, the estimated coefficients of the cost function are used to measure the marginal cost.

$$
\mathrm{MC}=\frac{\mathrm{TC}}{\mathrm{y}}\left(\alpha_{1}+\alpha_{2} \ln \mathrm{y}+\sum_{\mathrm{j}=1}^{3} \gamma_{\mathrm{j}} \ln \mathrm{w}_{\mathrm{j}}\right)
$$

The Lerner index of each bank for each period can be computed using equation (1) after the marginal cost and the price of output are calculated based on that bank's financial statements.

\subsection{Bank Efficiency}

To measure bank efficiency in Macau, we use DFA, a parametric approach, based on the earlier panel data approach developed by Schmidt and Sickles (1984). DFA separates the inefficiency term and the random error term. Due to the presence of random interference and inefficiency, the sample banks deviated from the efficient frontier bank, which refers to the bank that obtains the maximization of profit with minimum input based on given technical conditions and external market factors. In DFA analysis, the efficient frontier bank has its efficiency as 100\%. DFA does not specify the specific form of inefficiencies but assumes that inefficiencies are stable over time while random error tends to average out (Schmidt \& Sickles, 1984). This method requires the use of time-series and panel data in the regression, and the estimation of the bank's efficiency is a mixed estimate. Assume that the bank's cost function has the following logarithmic form:

where,

$$
\begin{aligned}
& \ln T C_{i t}=\ln f\left(y_{i t}, w_{i t}\right)+\varepsilon_{i t} \\
& \ln T C_{i t}=\ln f\left(y_{i t}, w_{i t}\right)+\ln x_{i}+\ln v_{i t}
\end{aligned}
$$

$T C$ is the total cost of $i$ bank in the $t$ period,

$f\left(y_{i t}, w_{i t}\right)$ is the cost function, $y_{i t}$ is the output price,

$w_{i t}$ are the input prices,

$x_{i}$ is the inefficient factor of the $i$ bank,

$v_{i t}$ is the random error for the $i$ bank in the $t$ period.

Under DFA's assumptions, each bank's inefficiency term remains constant for a certain period of time, except for all other elements in the equation (4) that are allowed to change over time.

The uniqueness of the DFA efficiency frontier function parameter is that it does not estimate the entire continuous time series panel data as a single cost function. Instead, it uses a year-by-year data to separately estimate a cost function. The difference in costs due to changes in technology and regulations in different years will be reflected by the parameters of the annual cost function. In addition, the inefficiency term and the random error term must be treated as a compound error in the estimation, as $\varepsilon_{i t}=\ln x_{i}+\ln v_{i t}$. Since the mean of the random error term is zero during the $t$ period, the mean of the compound error term is the inefficiency.

The definition of the distribution-free estimation for bank $i$ is as follows:

$$
d f e_{i}(T)=\frac{1}{T} \sum_{t=1}^{T} \ln \varepsilon_{i t}=\ln \widehat{x}_{\imath}
$$

where, $\mathrm{T}$ is the number of sample observation period, and the efficiency level of the investigated bank is a relative value to the efficiency level of the best performing bank in the sample:

where,

$$
E F F_{i}(T)=\exp \left[d f e_{\min }(T)-d f e_{i}(T)\right]
$$

$E F F_{i}(T)$ is the efficiency level of bank $i$,

$0<E F F_{i}(T) \leq 1, d f e_{\min }(\mathrm{T})$ is the minimum of all investigated bank inefficiencies, $E F F_{i}(T)$ increases with bank's cost efficiency. 


\subsection{Causality between Bank Competition and Efficiency}

To explore the relationship between bank competition and efficiency, the Granger causality test is used in this study. The advantage of this method is that it incorporates error correction so that the Granger causal analysis method can test long-term causality and short-term causality. Determining the direction of causality between competition (COM) and efficiency (EFF) can be tested by the two equations as:

$$
\begin{gathered}
\operatorname{COM}_{t}=\alpha_{0}+\sum_{i=1}^{m} \alpha_{i} \operatorname{COM}_{t-1}+\sum_{j=1}^{n} \alpha_{j} E F F_{t-j}+u_{t} \\
E F F_{t}=\beta_{0}+\sum_{i=1}^{m} \beta_{i} E F F_{t-1}+\sum_{j=1}^{n} \beta_{j} \operatorname{COM}_{t-j}+v_{t}
\end{gathered}
$$

where

$i$ represents the individual bank and $t$ denotes time

$\alpha_{i}, \alpha_{j}, \beta_{i}, \beta_{j}=$ parameters to be estimated

$\alpha_{0}, \beta_{0}=$ individual bank fixed effect

$u_{t}, v_{t}=$ error terms

$\operatorname{COM}_{t-1}=$ The Lerner index indicating bank competition of bank $i$ at $t-1$

$C O M_{t-j}=j^{\text {th }}$ lagged Lerner index indicating bank competition, $j=1,2, \ldots \mathrm{n}$

$E F F_{t-1}=$ cost efficiency of the bank $i$ at $t-1$

$E F F_{t-j}=j^{\text {th }}$ lagged cost efficiency, $j=1,2, \ldots \mathrm{n}$

Granger's causality indicates that the relationship between the Granger cause and do not Granger cause. It focuses on the confirmation of the direction of influence rather than the complete causality (Granger, 1969; Gujarati, 2003).

\subsection{Bank Stability}

In this study, following Agoraki, Delis, and Pasiouras (2011) and Soedarmono, Machrouh, and Tarazi (2011), financial stability is measured by bank income volatility, insolvency risk, and capitalization. The standard deviation of banks' return on average assets (SROA) and that of banks' return on average equity (SROE) are proxies of bank income volatility that reflects bank risk-taking strategies. SROA is computed from the return on average assets (ROAA) values taken from period t to $\mathrm{t}-2$ (a three-period rolling window). Analogically, SROE is calculated from the return on average equity (ROAE) using a three-period rolling window. To measure bank insolvency risk, the Z-score method based on ROAA is applied. The Z-score (ZROA) represents the number of standard deviations that the bank's ROAA has to fall below its expected value before equity is completely exhausted. Therefore, a higher Z-score can be interpreted as lower in bank insolvency risk (Soedarmono et al., 2011).

ZROA is formulated as follows:

where

$$
Z R O A i, t=(R O A A i, t+E Q T A i, t) /(S R O A i, t)
$$

$i$ represents the individual bank and $t$ denotes time

For robustness check, we also use the Z-score measure based on ROAE (ZROE) which is formulated as follows:

$$
Z R O E i, t=(R O A E i, t+1) /(S R O E i, t)
$$

Banks may reduce financial fragility by maintaining higher levels of capital that protect them from external economic and liquidity shocks (Amidu \& Wolfe, 2013). The leverage ratio can also serve as a measure to discipline bank moral hazard (Blum, 2008). To account for the levels of bank capitalization, we use the equity to total assets ratio (EQTA), as an indicator of leverage.

Following Soedarmono et al. (2011), we also include the four control variables. The loan-to-deposit ratio (LDR), which indicates bank liquidity that may affect bank default probability, is used to control for bank-specific characteristics. The loan growth rate (LOANG) is included since excessive loan growth can result in higher bank risk and lower capital ratios (Foos, Norden, \& Weber, 2010). The ratio of operating expenses to total assets (OVERHEAD) is a control for the differences in technical efficiency (Agoraki et al., 2011). Bank size (SIZE), defined as the logarithm of banks' total average assets to control for higher risk-taking to address "too big to fail" effects in larger banks (Mishkin, 2006).

To assess the impact of bank competition, proxied by the Lerner index, on financial stability, proxied by SROA, SROE, ZROA, ZROE and EQTA, we construct equation (11) following the existing literature (Agoraki et al., 2011; Soedarmono et al., 2011). 


$$
\begin{gathered}
\text { STABILITY } i, t=\alpha 1 L E R N E R i, t+\alpha 2 L D R i, t+\alpha 3 L O A N G i, t+\alpha 4 O V E R H E A D i, t \\
+\alpha 5 S I Z E i, t+\varepsilon i, t
\end{gathered}
$$

where

$i$ represents the individual bank and $t$ denotes time

Our main variable of interest is $\alpha_{1}$, the coefficient on the Lerner index, which captures the change in the association between bank competition and stability. A significantly positive $\alpha_{1}$ between SROA/SROE and the Lerner index testifies the competition-stability view, while a significantly negative one indicates the competition-fragility view. In the meantime, a significantly negative $\alpha_{1}$ between ZROA/ZROE and the Lerner index attests the competition-stability view, while a significantly positive one indicates the competition-fragility view in Macau.

\subsection{Bank Size}

We use loan rank (Tai, 2012) and the logarithm of total assets (Chen et al., 2005) to indicate bank size to examine the effect of bank size on bank efficiency measured by DFA approach mentioned in 3.3 to examine H4 of "bank size has no impact on bank efficiency in Macau."

\section{Results and Analysis}

\subsection{Descriptive Statistics}

As indicated in Table 1, the size of the banks and their operations varied significantly in terms of total assets and total loans. In the year 2016, Bank of China (BOC) and its affiliate Tai Fung Bank (TaiFung) had 40\% and $10 \%$ share of total loans, respectively, in Macau. BOC, with MOP 456 billion of total loans and MOP 538 billion of total assets, led the local banking sector, followed by Industrial and Commercial Bank of China Limited (C-ICBC) and TaiFung. The top three players occupy over $65 \%$ market share in both total loans and total assets, which indicates a relatively high market concentration. Banco Nacional Ultramarino S.A. (BNU), the other issuing bank authorized by AMCM to issue local banknotes denominated in Macanese Pataca (MOP) besides BOC, had a share of $4.4 \%$ of total loans and $4.3 \%$ of total assets. Citibank had only MOP 2 million total loans and MOP 5 million total assets which made it the smallest bank in Macau. 
Table 1. Total Loans and Total Assets, 2016

\begin{tabular}{|c|c|c|}
\hline Bank & $\begin{array}{c}\text { Total Loans } \\
\text { (MOP Million) }\end{array}$ & $\begin{array}{c}\text { Total Assets } \\
\text { (MOP Million) }\end{array}$ \\
\hline BOC & 455,684 & 538,464 \\
\hline TaiFung & 113,039 & 152,894 \\
\hline C-ICBC & 175,257 & 209,557 \\
\hline WH & 28,478 & 31,830 \\
\hline BPI & 874 & 877 \\
\hline BNU & 51,158 & 68,497 \\
\hline CITIC & 2,097 & 2,765 \\
\hline Construction Bank & 37,123 & 38,667 \\
\hline Wing Lung & 13,822 & 14,006 \\
\hline SinoPac & 3,249 & 3,369 \\
\hline Chinese Bank & 1,455 & 2,106 \\
\hline Guangfa & 22,241 & 26,731 \\
\hline Comercial Portugues & 10,468 & 10,930 \\
\hline HSBC & 21,502 & 23,152 \\
\hline Hua Nan & 4,547 & 4,657 \\
\hline Standard Chartered & 2,520 & 3,033 \\
\hline Chong Hing Bank & 2,726 & 2,949 \\
\hline First Commercial Bank & 1,671 & 1,774 \\
\hline Luso & 99,954 & 129,491 \\
\hline Banco Comercial & 16,949 & 19,445 \\
\hline DBS & 3,516 & 4,581 \\
\hline Hang Seng & 13,773 & 17,044 \\
\hline Citibank & 2 & 5 \\
\hline East Asia & 6,959 & 7,541 \\
\hline Bank of Communications & 49,629 & 58,793 \\
\hline Novo & 854 & 951 \\
\hline
\end{tabular}

Table 2 shows descriptive statistics of the key variables in 2016 used in the quantitative analysis. Two output variables, bank total loans had an average of MOP 43.8 billion and net loans of MOP 30.0 billion. Both had a high standard deviation of MOP 93.9 billion and MOP 61.5 billion, respectively, which indicates that the size of bank operations varied widely in Macau. Price of labor $\left(\mathrm{w}_{1}\right)$ had a mean of $0.36 \%$. Price of physical capital $\left(\mathrm{w}_{2}\right)$ had a mean of $25.96 \%$ and a standard deviation of $31.79 \%$. Price of borrowed funds defined $\left(\mathrm{w}_{3}\right)$ was $1.30 \%$ on average. Among other characteristics, average total assets were MOP 52.9 billion and average total costs were MOP 720 million. Both had wide variations. Price of loan, on average, was 3.86\%, which indicated an interest margin of $2.56 \%$ in 2016. 
Table 2. Descriptive Statistics, 2016

\begin{tabular}{ccc}
\hline Output & Mean & Standard Deviation \\
\hline Loans (MOP Million) & 43,829 & 93,873 \\
Net loans (MOP Million) & 30,029 & 61,522 \\
$\quad$ Input prices & & \\
Price of labor (\%) & 0.36 & 0.34 \\
Price of physical capital (\%) & 25.96 & 31.79 \\
Price of borrowed funds (\%) & 1.30 & 1.95 \\
Other characteristics & & 112,145 \\
Total assets (MOP millions) & 52,850 & 1,609 \\
Total costs (MOP millions) & 720 & 1.80 \\
Price of loans (\%) & 3.86 & \\
\hline
\end{tabular}

Note: $\mathrm{N}=26$ banks

\subsection{Bank Competition, Efficiency, and Causality}

Table 3 summarizes the mean, median and standard deviation of the Lerner Index for the sample banks from 1999 to 2016. Since the Lerner index, ranging between 0 to 1 , is an inverse measure of the competition, the level of competition of the Macau banking industry can be observed through its fluctuation over that period. Immediately after Macau's return to China in 1999, the competition in its banking sector started to decrease till 2003. The competition increased around the global financial crisis in 2007 and 2008 and decreased again in the recent two years. Using the Lerner index's mean of 0.5856 and median of 0.6119 in 1999 to compare against the most recent mean of 0.6307 and median of 0.6643 in 2016 , it indicates an overall lower level of competition or higher level of market concentration in 2016 than 1999.

Table 3. Lerner Index for All Banks, 1999-2016

\begin{tabular}{lllc}
\hline Year & Mean & Median & Standard Deviation \\
\hline $\mathbf{1 9 9 9}$ & 0.5856 & 0.6119 & 0.3021 \\
$\mathbf{2 0 0 0}$ & 0.6672 & 0.6756 & 0.1468 \\
$\mathbf{2 0 0 1}$ & 0.6342 & 0.6818 & 0.1974 \\
$\mathbf{2 0 0 2}$ & 0.6877 & 0.7350 & 0.1750 \\
$\mathbf{2 0 0 3}$ & 0.6986 & 0.7338 & 0.1602 \\
$\mathbf{2 0 0 4}$ & 0.6076 & 0.6951 & 0.2160 \\
$\mathbf{2 0 0 5}$ & 0.6251 & 0.6297 & 0.1615 \\
$\mathbf{2 0 0 6}$ & 0.6375 & 0.5937 & 0.1698 \\
$\mathbf{2 0 0 7}$ & 0.5238 & 0.5069 & 0.2152 \\
$\mathbf{2 0 0 8}$ & 0.5263 & 0.5262 & 0.1869 \\
$\mathbf{2 0 0 9}$ & 0.5949 & 0.6386 & 0.2431 \\
$\mathbf{2 0 1 0}$ & 0.6211 & 0.6446 & 0.1756 \\
$\mathbf{2 0 1 1}$ & 0.6192 & 0.6579 & 0.1862 \\
$\mathbf{2 0 1 2}$ & 0.5409 & 0.5951 & 0.2714 \\
$\mathbf{2 0 1 3}$ & 0.6186 & 0.6585 & 0.1847 \\
$\mathbf{2 0 1 4}$ & 0.5868 & 0.6157 & 0.1996 \\
$\mathbf{2 0 1 5}$ & 0.6177 & 0.6715 & 0.1945 \\
$\mathbf{2 0 1 6}$ & 0.6307 & 0.6643 & 0.1873 \\
\hline
\end{tabular}


The comparison of the Lerner index of individual banks in 1999 vs. 2016 is displayed in Table 4, which is used to signal the change of their market power in the competition. The increase of a bank's Lerner index reflects greater market power in the competition. On the contrary, the decrease of the Lerner index reflects the lower market power in the competition. 12 out of 26 banks, including the top three banks by size, managed to gain more market power over the years. Other 14 banks, including BNU, lost their market power at the same time.

Table 4. Lerner Index for Individual Banks, 1999-2016

\begin{tabular}{|c|c|c|c|}
\hline Bank & 1999 & 2016 & Comment \\
\hline BOC & 0.5791 & 0.6019 & Greater market power \\
\hline TaiFung & 0.5987 & 0.6070 & Greater market power \\
\hline C-ICBC & 0.4598 & 0.5834 & Greater market power \\
\hline WH & 0.6250 & 0.6024 & Less market power \\
\hline BPI & $0.9932^{1}$ & 0.9944 & Greater market power \\
\hline BNU & 0.7224 & 0.6876 & Less market power \\
\hline CITIC & $0.1869^{1}$ & 0.6989 & Greater market power \\
\hline Construction Bank & 0.5484 & 0.3735 & Less market power \\
\hline Wing Lung & $0.6687^{2}$ & 0.7850 & Greater market power \\
\hline SinoPac & 0.4278 & 0.7178 & Greater market power \\
\hline Chinese Bank & 0.5910 & 0.1655 & Less market power \\
\hline Guangfa & 0.5263 & 0.4151 & Less market power \\
\hline Comercial Portugues & 0.9638 & 0.8842 & Less market power \\
\hline HSBC & 0.7030 & 0.7265 & Greater market power \\
\hline Hua Nan & $0.7112^{3}$ & 0.8731 & Greater market power \\
\hline Standard Chartered & $0.8930^{3}$ & 0.7477 & Less market power \\
\hline Chong Hing Bank & 0.7907 & 0.7556 & Less market power \\
\hline First Commercial Bank & $0.5520^{4}$ & 0.6161 & Greater market power \\
\hline Luso & 0.3692 & 0.2719 & Less market power \\
\hline Banco Comercial & 0.6281 & 0.5290 & Less market power \\
\hline DBS & 0.6576 & 0.6853 & Greater market power \\
\hline Hang Seng & $0.3507^{5}$ & 0.7090 & Greater market power \\
\hline Citibank & 0.9994 & 0.8110 & Less market power \\
\hline East Asia & $0.7434^{6}$ & 0.5025 & Less market power \\
\hline Bank of Communications & $0.5038^{7}$ & 0.4110 & Less market power \\
\hline Novo & 0.8144 & 0.6434 & Less market power \\
\hline
\end{tabular}

The DFA approach is employed for all 26 banks operating through the study period to explore the banking efficiency in Macau from 1999 to 2016. Table 5 shows OCBC Wing Hang Bank Limited (WH) was the most efficient bank in Macau throughout the entire study period. All other banks had values between 1 and 0 . Higher efficiency led to an efficiency score closer to 1. First Commercial Bank and Chong Hing Bank had an efficiency score of 0.9905 and 0.9771, respectively, indicating that there were the highly efficient banks next to WH. Luso (efficiency score of 0.6842), Citibank (0.7401), the Chinese Bank and TaiFung (both at 0.8062) were the least efficient banks in Macau. Being the top three banks in terms of total loans and total assets, BOC (0.8304), C-ICBC (0.8076) and TaiFung (0.8062) had efficiency scores lower than the mean and median. It showed that the top three banks had 16.96\%, $19.24 \%$ and $19.38 \%$ possibility of output improvement under the conditions of no extra input. Between two issuing banks, BNU (0.9044)'s efficiency score was higher than BOC (0.8304). Among the 26 banks in the survey, there were only 10 banks whose efficiency score was higher than 0.9 . Most banks have the opportunity to improve efficiency or the possibility of an increase in output at the current level of input. The initial comparison using bank size (Table 1), market power (Lerner index in Table 4) and bank efficiency (Table 5) indicates that large banks with greater market power were actually less efficient than their smaller counterparts. 
Table 5. Banking Efficiency, 1999-2016

\begin{tabular}{|c|c|}
\hline Bank & Efficiency Score \\
\hline BOC & 0.8304 \\
\hline TaiFung & 0.8062 \\
\hline C-ICBC & 0.8076 \\
\hline WH & 1.0000 \\
\hline BPI & 0.8858 \\
\hline BNU & 0.9044 \\
\hline CITIC & 0.9669 \\
\hline Construction Bank & 0.9252 \\
\hline Wing Lung & 0.8962 \\
\hline SinoPac & 0.8366 \\
\hline Chinese Bank & 0.8062 \\
\hline Guangfa & 0.8123 \\
\hline Comercial Portugues & 0.9567 \\
\hline HSBC & 0.8938 \\
\hline Hua Nan & 0.8765 \\
\hline Standard Chartered & 0.8903 \\
\hline Chong Hing Bank & 0.9771 \\
\hline First Commercial Bank & 0.9905 \\
\hline Luso & 0.6842 \\
\hline Banco Comercial & 0.8602 \\
\hline DBS & 0.9276 \\
\hline Hang Seng & 0.8559 \\
\hline Citibank & 0.7401 \\
\hline East Asia & 0.9484 \\
\hline Bank of Communications & 0.9261 \\
\hline Novo & 0.8273 \\
\hline
\end{tabular}

Table 6 displays the average Lerner index (an inverse indicator of competition) and efficiency score for all 26 banks in the sample from 1999 to 2016 . A negative, but not statistically significant relationship between the Lerner index and efficiency can be observed over that period, which seems to imply competition and efficiency were heading in the same direction. Another noticeable observation is that, right after the global financial crisis, Macau's banking sector experienced relatively high competition and high efficiency from 2009 to 2012. 
Table 6. Average Lerner Index and Efficiency Score, 1999-2016

\begin{tabular}{ccc}
\hline Year & Lerner Index & Efficiency Score \\
\hline $\mathbf{1 9 9 9}$ & 0.5856 & 0.6497 \\
$\mathbf{2 0 0 0}$ & 0.6672 & 0.6407 \\
$\mathbf{2 0 0 1}$ & 0.6342 & 0.6935 \\
$\mathbf{2 0 0 2}$ & 0.6877 & 0.7051 \\
$\mathbf{2 0 0 3}$ & 0.6986 & 0.6655 \\
$\mathbf{2 0 0 4}$ & 0.6076 & 0.6639 \\
$\mathbf{2 0 0 5}$ & 0.6251 & 0.5673 \\
$\mathbf{2 0 0 6}$ & 0.6375 & 0.8284 \\
$\mathbf{2 0 0 7}$ & 0.5238 & 0.6795 \\
$\mathbf{2 0 0 8}$ & 0.5263 & 0.5623 \\
$\mathbf{2 0 0 9}$ & 0.5949 & 0.7760 \\
$\mathbf{2 0 1 0}$ & 0.6211 & 0.7742 \\
$\mathbf{2 0 1 1}$ & 0.6192 & 0.7737 \\
$\mathbf{2 0 1 2}$ & 0.5409 & 0.8059 \\
$\mathbf{2 0 1 3}$ & 0.6186 & 0.7600 \\
$\mathbf{2 0 1 4}$ & 0.5868 & 0.5419 \\
$\mathbf{2 0 1 5}$ & 0.6177 & 0.7374 \\
$\mathbf{2 0 1 6}$ & 0.6307 & 0.7705
\end{tabular}

Table 7 presents a key conclusion of our research through the pairwise Granger causality test, which addresses our first research proposition to examine the causality between bank efficiency and competition in Macau. The $p$-Value of 0.029 for the test of "competition does not Granger cause efficiency" leads to a rejection of H1 null hypothesis. Therefore, the alternative hypothesis "competition does Granger cause efficiency" should be accepted. Such finding provides empirical evidence to support that a high level of competition would cause high efficiency in the banking industry in Macau, which offers valuable support to the practitioners and policymakers to encourage competition in Macau's banking sector. The $\mathrm{H} 2$ null hypothesis of "efficiency does not Granger cause competition" has the $p$-Value of 0.130 and cannot be rejected, which provides no evidence to judge the causation from efficiency to competition in Macau's banking sector. The conclusion drawn for the first research proposition regarding the causality between bank competition and efficiency is in line with the competition-efficiency hypothesis (Berger \& Hannan, 1998). One possible explanation is that banks were forced to lower the costs to improve efficiency to respond to decreasing market power in a more competitive market environment. A good example is that banks in Macau were having an overall relatively low Lerner index (indicating less market power or greater competition) but high efficiency score right after the 2008 financial crisis (between 2009 to 2012).

Table 7. Pairwise Granger Causality Test Results, 1999-2016

\begin{tabular}{ccc}
\hline Null Hypothesis & F-Statistics & $p$-Value \\
\hline Competition does not Granger cause efficiency & 33.363 & 0.029 \\
Efficiency does not Granger cause competition & 6.996 & 0.130
\end{tabular}

To test the robustness of the conclusion related to our first research proposition, we use HHI instead of the Lerner index as the indicator of market concentration or competition in Macau, and find very similar results on $\mathrm{H} 1$ and $\mathrm{H} 2$ null hypotheses ( $p$-Value of 0.029 and 0.340 respectively) demonstrated in Table 8, which, again, support competition does Granger cause efficiency in Macau. 
Table 8. Pairwise Granger Causality Test Results Using HHI and Efficiency Score, 1999-2016

\begin{tabular}{crr}
\hline Null Hypothesis & F-Statistics & $p$-Value \\
\hline Competition does not Granger cause efficiency & 9.014 & 0.029 \\
Efficiency does not Granger cause competition & 3.289 & 0.349
\end{tabular}

\subsection{Bank Competition and Stability}

Table 9 summarizes the results related to the second research proposition of "whether there is an association between bank competition and stability in Macau." The previous study of Asia markets around Macau finds that the degree of market power (LERNER) is positively correlated to bank income volatility proxied by either SROA or SROE. Higher LERNER further intensifies bank insolvency risk proxied by ZROA or ZROE. Moreover, higher LERNER is also associated with an increase in capital ratios (EQTA) (Soedarmono et al., 2011). Our findings demonstrate the same direction between each dependent variable indicating bank stability and the independent variable, the Lerner index, indicating inverse competition or market power, as Soedarmono et al. (2011). In particular, in Equation (11), $\alpha_{1}$ is 0.380 (SROA), 44.100 (SROE), -10.255 (ZROA), and -3.110 (ZROE), respectively, which seems to point towards the path of competition-stability theory, but none of $\alpha_{1}$ is statistically significant ( $p$-value above $10 \%$ ). Therefore, we cannot reject the null hypothesis of $\mathrm{H} 3$ stating that "bank competition does not impact bank stability in Macau."

Table 9. The Nexus between Bank Competition and Stability

\begin{tabular}{cccccc}
\hline & SROA & SROE & ZROA & ZROE & EQTA \\
\hline \multirow{2}{*}{ LERNER $_{\mathbf{i}}$} & 0.380 & 44.100 & -10.255 & -3.110 & 0.327 \\
& $(0.285)$ & $(47.465)$ & $(18.588)$ & $(11.297)$ & $(1.483)$ \\
LDR $_{\mathbf{i}, \mathbf{t}}$ & 0.010 & 1.493 & 1.610 & 0.004 & $0.934^{*}$ \\
& $(0.060)$ & $(8.394)$ & $(2.130)$ & $(0.225)$ & $(0.493)$ \\
LOANG $_{\mathbf{i}, \mathbf{t}}$ & $8.778^{* * *}$ & $0.211^{* * *}$ & 0.195 & $-0.443^{* *}$ & 0.002 \\
& $(0.394)$ & $(0.027)$ & $(2.498)$ & $(0.207)$ & $(0.002)$ \\
OVERHEAD $_{\mathbf{i}, \mathbf{t}}$ & 0.429 & 0.158 & $0.878^{* * *}$ & -0.008 & $0.123^{* * *}$ \\
& $(5.225)$ & $(0.591)$ & $(0.298)$ & $(0.025)$ & $(0.038)$ \\
SIZE $_{\mathbf{i}, \mathbf{t}}$ & -0.150 & -13.930 & 4.818 & $0.974^{* *}$ & $-1.132^{* *}$ \\
R-square $_{\text {Obs. }}$ & $(0.103)$ & $(9.220)$ & $(4.631)$ & $(0.431)$ & $(0.546)$ \\
& 0.11 & 0.23 & 0.12 & 0.12 & 0.09 \\
\hline
\end{tabular}

Notes: 1. SROA, SROE, ZROA, ZROE are calculated using a three-year rolling window. All independent variables are calculated as one-year lag to avoid reverse-causality. $* * *, * * *$ indicates significance level at $1 \%, 5 \%$, and $10 \%$, respectively. 2. To eliminate the impacts of apparent outliers, observations with an independent variable outside 2 standard deviations are omitted. Thus, the observation numbers of different regressions are not consistent.

\subsection{Bank Size and Efficiency}

In Table 10, the Spearman Rank Correlation is used to examine H4 of "bank size has no impact on bank efficiency in Macau" by exploring the relationship between efficiency proxied by efficiency rank and bank size proxied by loan rank in 2016. The correlation coefficient between efficiency rank and loan rank is negative (-0.1159), but not statistically significant $(p=0.5729)$. Thus, we cannot reject the null hypothesis of H4. The economies of scale don't necessarily bring about efficiency in Macau's banking industry, which is consistent with the findings in the U.S. market (Ferrier \& Lovell, 1990) and Italian banks (Girardone et al., 2004). Our result also partially echoes, at least from the direction perspective, the previous finding of a negative correlation between the scale of bank and efficiency in Macau (Fu \& Vong, 2011). One possible explanation is that large banks open and maintain more branches in this tiny market, which would certainly increase their costs but may not necessarily generate additional output or loans proportionately. Another possibility is that small banks can rely on new technologies such as online banking and mobile banking to efficiently penetrate the market without adding additional branches and personnel. 
Table 10. Spearman Rank Correlation between Efficiency and Size

\begin{tabular}{clc}
\hline Bank & Efficiency Rank & Loan Rank, 2016 \\
\hline WH & 1 & 8 \\
First Commercial Bank & 2 & 22 \\
Chong Hing Bank & 3 & 19 \\
CITIC & 4 & 21 \\
Comercial Portugues & 5 & 14 \\
East Asia & 6 & 15 \\
DBS & 7 & 17 \\
Bank of Communications & 8 & 6 \\
Construction Bank & 9 & 7 \\
BNU & 10 & 5 \\
Wing Lung & 11 & 12 \\
HSBC & 12 & 10 \\
Standard Chartered & 13 & 20 \\
BPI & 14 & 24 \\
Hua Nan & 15 & 16 \\
Banco Comercial & 16 & 11 \\
Hang Seng & 17 & 13 \\
SinoPac & 18 & 18 \\
BOC & 19 & 1 \\
Novo & 20 & 25 \\
Guangfa & 21 & 9 \\
C-ICBC & 22 & 2 \\
TaiFung & 23 & 3 \\
Chinese Bank & 24 & 26 \\
Citibank & 25 & 4 \\
Luso & 26 & 23 \\
\hline
\end{tabular}

Note: The correlation coefficient between efficiency rank and loan rank was negative (-0.1159), but not statistically significant $(p=0.5729)$. Thus, we cannot reject the H4 indicating that efficiency rank is independent with loan rank, which means a bank's loan size does not have significant impacts on its relative efficiency.

To test the robustness of this conclusion, we use individual bank efficiency score instead of efficiency rank as the indicator of bank efficiency, and the logarithm of total assets instead of loan rank as the indicator of bank size to find a similar result. The correlation coefficient between bank efficiency and size is negative (-0.000 16), but not statistically significant ( $p=0.9811$, untabulated).

\section{Conclusions, Limitations and Future Research}

The banking industry is critical to the success of Macau's local economy and its future development. In this study, using a sample of 26 banks in Macau including all banks with normal operations to represent the evolvement of Macau's banking industry after its return to China in 1999 to 2016, we are the first as we know of to thoroughly explore the relationship of bank competition, efficiency, and stability in Macau. Our research contributes to the literature by identifying that bank competition does cause efficiency in Macau over that period. We also find indications of a positive but not significant connection between Macau bank competition and bank stability. Thirdly, this study finds no clear evidence that bank size would impact efficiency. Economies of scale or market share don't necessarily bring cost efficiency in Macau's banking industry.

The aforementioned findings have strong implications for academics, practitioners, and policymakers. Locally, the top three players in the banking sector already controlled over $65 \%$ share of total loan and total assets, and managed to successfully gain greater market power. It is particularly meaningful for the policymakers to closely monitor the market concentration and the market power of the leading players to maintain bank efficiency and financial stability in this small but wealthy market. 
There are several limitations of our study. First, due to the relatively small size of the Macau market, we can only include 26 banks in our research which may cause a concern of sample size. Second, for each key variable, such as bank competition and efficiency, we choose a limited number of measures in this study. Furthermore, endogeneity has always been an issue, especially in complicated causality relations related to bank competition and efficiency.

For future research, we recommend using different methods to capture bank competition and efficiency to verify our results. To mitigate the endogeneity issue, Gaussian Mixture Model, instrumental variables, fixed-effect models, and additional more meaningful control variables can be considered as effective remedies ( $\mathrm{Li}, 2016)$ in the future study.

Research on bank competition and efficiency has been a popular stream of literature in the past two decades. Different measures and approaches have been adopted to study the banking industry in various markets. With China's "One Belt, One Road" initiative and the "Guangdong-Hong Kong-Macau Greater Bay Area" (GBA) development plan, Macau would play a more active role in the regional even global economy. Based on the findings of our research, it would be fruitful to further benchmark Macau's banking sector against its counterparts in the Pearl Delta area and Hong Kong to identify opportunity areas for its future improvement. Such comparison would also offer more insights to the banking industry in the GBA which composes a unique sample set with strong multilateral economic ties under different social systems, regulatory environment, and market conditions.

\section{References}

Agoraki, M.-E., Delis, M. \& Pasiouras, F. (2011). Regulations, competition and bank risk-taking in transition countries. Journal of Financial Stability, 7(1), 38-48.

Allen, L. \& Rai, A. (1996). Operational efficiency in banking: An international comparison. Journal of Banking \& Finance, 20(4), 655-672. https://doi.org/10.1016/0378-4266(95)00026-7

Altunbas, Y., Liu, M.-H., Molyneux, P. \& Seth, R. (2000). Efficiency and risk in Japanese banking. Journal of Banking \& Finance, 24(10), 1605-1628. https://doi.org/10.1016/S0378-4266(99)00095-3

Amidu, M. \& Wolfe, S. (2013). Does bank competition and diversification lead to greater stability? Evidence from emerging markets. Review of Development Finance, 3(3), 152-166. https://doi.org/10.1016/j.rdf.2013.08.002

Andrieş, A. M. \& Căpraru, B. (2014). The nexus between competition and efficiency: The European banking industries experience. International Business Review, 23(3), 566-579. https://doi.org/10.1016/j.ibusrev.2013.09.004

Apergis, N. (2015). Competition in the banking sector: New evidence from a panel of emerging market economies and the financial crisis. Emerging Markets Review, 25, 154-162. https://doi.org/10.1016/j.ememar.2015.08.001

Bain, J. (1956). Barriers to New Competition. Retrieved from https://www.hup.harvard.edu/catalog.php?isbn=9780674188037

Banker, R. D., Cummins, J. D. \& Klumpes, P. J. M. (2010). Performance measurement in the financial services sector: Frontier efficiency methodologies and other innovative techniques. Journal of Banking \& Finance, 34(7), 1413-1416.

Baumol, W. J., Panzar, J. C. \& Willig, R. D. (1983). Contestable Markets: An Uprising in the Theory of Industry Structure: Reply. The American Economic Review, 73(3), 491-496.

Beck, T., De Jonghe, O. \& Schepens, G. (2013). Bank competition and stability: Cross-country heterogeneity. Journal of Financial Intermediation, 22(2), 218-244. https://doi.org/10.1016/j.jfi.2012.07.001

Beck, T., Demirgüç-Kunt, A. \& Levine, R. (2006). Bank concentration, competition, and crises: First results. Journal of Banking \& Finance, 30(5), 1581-1603. https://doi.org/10.1016/j.jbankfin.2005.05.010

Beck, T., Demirgüç-Kunt, A. \& Maksimovic, V. (2004). Bank competition and access to finance: International evidence. Proceedings, Federal Reserve Bank of Cleveland, 627-654.

Berger, A. N. \& Hannan, T. H. (1998). The Efficiency Cost of Market Power in the Banking Industry: A Test of the "Quiet Life" and Related Hypotheses. The Review of Economics and Statistics, 80(3), 454-465. Retrieved from JSTOR.

Berger, A. N., Klapper, L. F. \& Turk-Ariss, R. (2009). Bank Competition and Financial Stability. Journal of Financial Services Research, 35(2), 99-118. https://doi.org/10.1007/s10693-008-0050-7

Berger, A. N. \& Mester, L. J. (1997). Inside the black box: What explains differences in the efficiencies of financial institutions? Journal of Banking \& Finance, 21(7), 895-947. https://doi.org/10.1016/S0378-4266(97)00010-1 
Bhatia, V., Basu, S., Mitra, S. K. \& Dash, P. (2018). A review of bank efficiency and productivity. OPSEARCH, 55(3), 557-600. https://doi.org/10.1007/s12597-018-0332-2

Bikker, J. A., Shaffer, S. \& Spierdijk, L. (2012). Assessing Competition with the Panzar-Rosse Model: The Role of Scale, Costs, and Equilibrium. Review of Economics and Statistics, 94(4), 1025-1044. https://doi.org/10.1162/REST_a_00210

Blum, J. (2008). Why "Basel II" may need a leverage ratio restriction. Journal of Banking \& Finance, 32(8), 1699-1707.

Boone, J. (2008). A New Way to Measure Competition. The Economic Journal, 118(531), 1245-1261. https://doi.org/10.1111/j.1468-0297.2008.02168.x

Boyd, J. H. \& De Nicoló, G. (2005). The Theory of Bank Risk Taking and Competition Revisited. The Journal of Finance, 60(3), 1329-1343. Retrieved from JSTOR.

Boyd, J. H., De Nicoló, G. \& Smith, B. D. (2004). Crises in Competitive versus Monopolistic Banking Systems. Journal of Money, Credit and Banking, 36(3), 487-506. Retrieved from JSTOR.

Bresnahan, T. F. (1989). Chapter 17 Empirical studies of industries with market power. In Handbook of Industrial Organization (Vol. 2, pp. 1011-1057). https://doi.org/10.1016/S1573-448X(89)02005-4

Carvallo, O. \& Kasman, A. (2005). Cost efficiency in the Latin American and Caribbean banking systems. Journal of International Financial Markets, Institutions and Money, 15(1), 55-72. https://doi.org/10.1016/j.intfin.2004.02.002

Casu, B. \& Girardone, C. (2006). Bank Competition, Concentration and Efficiency in the Single European Market. The Manchester School, 74(4), 441-468. https://doi.org/10.1111/j.1467-9957.2006.00503.x

Cavallo, L. \& Rossi, S. P. S. (2002). Do environmental variables affect the performance and technical efficiency of the European banking systems? A parametric analysis using the stochastic frontier approach. The European Journal of Finance, 8(1), 123-146. https://doi.org/10.1080/13518470110076277

Chandler, A. D. (1977). The Visible hand: The managerial revolution in American business. Retrieved from http://archive.org/details/visiblehandmanag00chan

Charnes, A., Cooper, W. W. \& Rhodes, E. (1978). Measuring the efficiency of decision making units. European Journal of Operational Research, 2(6), 429-444. https://doi.org/10.1016/0377-2217(78)90138-8

Chen, X., Skully, M. \& Brown, K. (2005). Banking efficiency in China: Application of DEA to pre- and post-deregulation eras: 1993-2000. China Economic Review, 16(3), 229-245. https://doi.org/10.1016/j.chieco.2005.02.001

Claessens, S. \& Laeven, L. (2004). What Drives Bank Competition? Some International Evidence. Journal of Money, Credit and Banking, 36(3), 563-583. Retrieved from JSTOR.

Claessens, S. \& Laeven, L. (2005). Financial Dependence, Banking Sector Competition, and Economic Growth. Journal of the European Economic Association, 3(1), 179-207. https://doi.org/10.1162/1542476053295322

Clerides, S., Delis, M. D. \& Kokas, S. (2015). A New Data Set on Competition in National Banking Markets. Financial Markets, Institutions \& Instruments, 24(2-3), 267-311. https://doi.org/10.1111/fmii.12030

Corrigan, E. G. (1982). Are banks special? Annual Report from Federal Reserve Bank of Minneapolis. Retrieved from https://econpapers.repec.org/article/fipfedmar/y_3a1982.htm

De Jonghe, O. \& Vennet, R. V. (2008). Competition versus efficiency: What drives franchise values in European banking? Journal of Banking and Finance, 32(9), 1820-1835. https://doi.org/10.1016/j.jbankfin.2007.12.009

De Nicolo, G., Jalal, A. M. \& Boyd, J. H. (2006). Bank Risk-Taking and Competition Revisited; New Theory and New Evidence (IMF Working Paper No. 06/297). Retrieved from International Monetary Fund website: https://econpapers.repec.org/paper/imfimfwpa/06_2f297.htm

Delis, M. D. \& Tsionas, E. G. (2009). The joint estimation of bank-level market power and efficiency. Journal of Banking \& Finance, 33(10), 1842-1850. https://doi.org/10.1016/j.jbankfin.2009.04.006

Demsetz, H. (1973). Industry Structure, Market Rivalry, and Public Policy. Journal of Law and Economics, 16(1), $1-9$. 
Demsetz, R. S., Saidenberg, M. R. \& Strahan, P. E. (1996). Banks with Something to Lose: The Disciplinary Role of Franchise Value (SSRN Scholarly Paper No. ID 1028769). Retrieved from Social Science Research Network website: https://papers.ssrn.com/abstract=1028769

Deprins, D., Simar, L. \& Tulkens, H. (1984). Measuring labor-efficiency in post offices (CORE Discussion Papers RP No. 571). Retrieved from Université catholique de Louvain, Center for Operations Research and Econometrics (CORE) website: https://econpapers.repec.org/paper/corlouvrp/571.htm

Diallo, B. (2015). Bank competition and crises revisited: New results. Economics Letters, 129, 81-86. https://doi.org/10.1016/j.econlet.2015.02.015

Dubovik, A. \& Kalara, N. (2018). Can we measure banking sector competition robustly? (No. 386). Retrieved from CPB Netherlands Bureau for Economic Policy Analysis website: https://ideas.repec.org/p/cpb/discus/386.html

Fernandez de Guevara, J. \& Maudos, J. (2009). Regional Financial Development and Bank Competition: Effects on Firms' Growth. IDEAS Working Paper Series from RePEc. Retrieved from http://search.proquest.com/docview/1699207625/?pq-origsite=primo

Ferrier, G. D. \& Lovell, C. A. K. (1990). Measuring cost efficiency in banking: Econometric and linear programming evidence. Journal of Econometrics, 46(1), 229-245. https://doi.org/10.1016/0304-4076(90)90057-Z

Fethi, M. D. \& Pasiouras, F. (2009). Assessing Bank Efficiency and Performance with Operational Research and Artificial Intelligence Techniques: A Survey (SSRN Scholarly Paper No. ID 1350544). Retrieved from Social Science Research Network website: https://papers.ssrn.com/abstract=1350544

Foos, D., Norden, L. \& Weber, M. (2010). Loan growth and riskiness of banks. Journal of Banking \& Finance, 34(12), 2929-2940.

Fu, X. \& Vong, A. (2011). Bank efficiency and productivity change in Hong Kong and Macao. Macau Monetary Research Bulletin, 18.

Fungáčová, Z., Pessarossi, P. \& Weill, L. (2013). Is bank competition detrimental to efficiency? Evidence from China. China Economic Review, 27, 121-134. https://doi.org/10.1016/j.chieco.2013.09.004

Girardone, C., Molyneux, P. \& Gardener, E. P. M. (2004). Analysing the determinants of bank efficiency: The case of Italian banks. Applied Economics, 36(3), 215-227. https://doi.org/10.1080/0003684042000175334

Gong, F. \& Lin, S. W. (2011). Bank efficiency and productivity in Macau: A Bootstrap DEA Approach. Journal of One Country Two Systems Research Centre, 9, 123-131.

Granger, C. W. J. (1969). Investigating Causal Relations by Econometric Models and Cross-spectral Methods. Econometrica, 37(3), 424-438. https://doi.org/10.2307/1912791

Gujarati, D. N. (2003). Basic econometrics (4th ed). Boston: McGraw Hill.

Hellmann, T. F., Murdock, K. C. \& Stiglitz, J. E. (2000). Liberalization, Moral Hazard in Banking, and Prudential Regulation: Are Capital Requirements Enough? American Economic Review, 90(1), 147-165. https://doi.org/10.1257/aer.90.1.147

Hughes, J. P. \& Mester, L. J. (2013). Measuring the performance of banks: Theory, practice, evidence, and some policy implications (No. 13-31). Retrieved from Federal Reserve Bank of Philadelphia website: https://ideas.repec.org/p/fip/fedpwp/13-31.html

Keeley, M. C. (1990). Deposit Insurance, Risk, and Market Power in Banking. The American Economic Review, $80(5), 1183-1200$.

Koetter, M., Kolari, J. W. \& Spierdijk, L. (2008). Efficient competition? Testing the "quiet life" of US banks with adjusted Lerner indices. IDEAS Working Paper Series. Retrieved from http://search.proquest.com/docview/1698098972?rfr_id=info\%3Axri\%2Fsid\%3Aprimo

Kumbhakar, S. C. \& Wang, D. (2007). Economic reforms, efficiency and productivity in Chinese banking. Journal of Regulatory Economics, 32(2), 105-129. https://doi.org/10.1007/s11149-007-9028-x

Lang, G. \& Welzel, P. (1996). Efficiency and technical progress in banking Empirical results for a panel of German cooperative banks. Journal of Banking \& Finance, 20(6), 1003-1023. https://doi.org/10.1016/0378-4266(95)00040-2 
Li, F. (2016). Endogeneity in CEO power: A survey and experiment. Investment Analysts Journal, 45(3), 149-162. https://doi.org/10.1080/10293523.2016.1151985

Martinez-Miera, D. \& Repullo, R. (2010). Does Competition Reduce the Risk of Bank Failure? The Review of Financial Studies, 23(10), 3638-3664. https://doi.org/10.1093/rfs/hhq057

Maudos, J., Pastor, J. M., Pérez, F. \& Quesada, J. (2002). Cost and profit efficiency in European banks. Journal of International Financial Markets, Institutions and Money, 12(1), 33-58. https://doi.org/10.1016/S1042-4431(01)00051-8

Mendes, V. \& Rebelo, J. (2000). Sources of Productivity Change in Banking in Macau. Euro Asia Journal of Management, 7-24.

Mertens, A. \& Urga, G. (2001). Efficiency, scale and scope economies in the Ukrainian banking sector in 1998. Emerging Markets Review, 2(3), 292-308. https://doi.org/10.1016/S1566-0141(01)00022-X

Mishkin, F. (1999). Financial consolidation: Dangers and opportunities. Journal of Banking \& Finance, 23(2), 675-691. https://doi.org/10.1016/S0378-4266(98)00084-3

Mishkin, F. (2006). How Big a Problem is Too Big to Fail? A Review of Gary Stern and Ron Feldman's Too Big to Fail: The Hazards of Bank Bailouts. Journal of Economic Literature, 44(4), 988-1004. https://doi.org/10.1257/jel.44.4.988

Panzar, J. C. \& Rosse, J. N. (1987). Testing For "Monopoly" Equilibrium. The Journal of Industrial Economics, 35(4), 443-456. https://doi.org/10.2307/2098582

Peltzman, S. (1977). The Gains and Losses from Industrial Concentration. Journal of Law and Economics, 20(2), 229-263.

Perera, S., Skully, M. \& Wickramanayake, J. (2007). Cost Efficiency in South Asian Banking: The Impact of Bank Size, State Ownership and Stock Exchange Listings. International Review of Finance, 7(1-2), 35-60. https://doi.org/10.1111/j.1468-2443.2007.00067.x

Saif-Alyousfi, A. Y. H., Saha, A. \& Md-Rus, R. (2018). The impact of bank competition and concentration on bank risk-taking behavior and stability: Evidence from GCC countries. The North American Journal of Economics and Finance, https://doi.org/10.1016/j.najef.2018.10.015

Saurina Salas, J., Jiménez, G. \& Lopez, J. A. (2007). How Does Competition Impact Bank Risk Taking? (SSRN Scholarly Paper No. ID 965462). Retrieved from Social Science Research Network website: https://papers.ssrn.com/abstract=965462

Schaeck, K. \& Čihák, M. (2008). How does competition affect efficiency and soundness in banking? New empirical evidence. ECB Working Paper No. 932, 46.

Schaeck, K. \& Čihák, M. (2014). Competition, Efficiency, and Stability in Banking. Financial Management (Wiley-Blackwell), 43(1), 215-241. https://doi.org/10.1111/fima.12010

Schmidt, P. \& Sickles, R. (1984). Production Frontiers and Panel Data. Journal of Business \& Economic Statistics, 2(4), 367-374.

Sheldon, D. (2015). Macau V Las Vegas: Which Destination Stacks Up Best? Retrieved April 17, 2019, from Casino.org Blog website: https://www.casino.org/blog/macau-v-las-vegas-which-destination-stacks-up-best/

Sheng, M. \& Gu, C. (2018). Economic growth and development in Macau (1999-2016) - The role of the booming gaming industry | Elsevier Enhanced Reader. Cities. https://doi.org/10.1016/j.cities.2018.01.003

Simar, L. \& Wilson, P. W. (2013). Estimation and Inference in Nonparametric Frontier Models: Recent Developments and Perspectives. Foundations and Trends ${ }^{\circledR}$ in Econometrics, 5(3-4), 183-337. https://doi.org/10.1561/0800000020

Soedarmono, W., Machrouh, F. \& Tarazi, A. (2011). Bank market power, economic growth and financial stability: Evidence from Asian banks. Journal of Asian Economics, 22(6), 460-470. https://doi.org/10.1016/j.asieco.2011.08.003

Staikouras, C. K. \& Koutsomanoli-Fillipaki, A. (2006). Competition and Concentration in the New European Banking Landscape. European Financial Management, $12(3), \quad 443-482$. https://doi.org/10.1111/j.1354-7798.2006.00327.x 
Tai, L. S. (2012). Competition and Efficiency of National Banks in the United Arab Emirates. The Journal of Applied Business and Economics; Thunder Bay, 13(5), 76-86.

Tan, Y. (2016). The impacts of risk and competition on bank profitability in China. Journal of International Financial Markets, Institutions \& Money, 40(C), 85-110. https://doi.org/10.1016/j.intfin.2015.09.003

Tan, Y. \& Floros, C. (2018). Risk, competition and efficiency in banking: Evidence from China. Global Finance Journal, 35, 223-236. https://doi.org/10.1016/j.gfj.2017.12.001

Tan, Y., Floros, C. \& Anchor, J. (2017). The profitability of Chinese banks: Impacts of risk, competition and efficiency. Review of Accounting and Finance, 16(1), 86-105. https://doi.org/10.1108/RAF-05-2015-0072

The World Bank. (2018). Global Financial Development Report 2017/2018. World Bank Publications, The World Bank Group, 181.

Tone, K. (2004). Malmquist Productivity Index. In W. W. Cooper, L. M. Seiford \& J. Zhu (Eds.), Handbook on Data Envelopment Analysis (pp. 203-227). https://doi.org/10.1007/1-4020-7798-X_8

Uhde, A. \& Heimeshoff, U. (2009). Consolidation in banking and financial stability in Europe: Empirical evidence. Journal of Banking \& Finance, 33(7), 1299-1311. https://doi.org/10.1016/j.jbankfin.2009.01.006

Yeyati, E. L. \& Micco, A. (2007). Concentration and foreign penetration in Latin American banking sectors: Impact on competition and risk. Journal of Banking \& Finance, 31(6), 1633-1647. https://doi.org/10.1016/j.jbankfin.2006.11.003

\section{Notes}

Note 1. The Statistics and Census Service Department, Macau SAR. (2016). The Per Capita GDP. Retrieved from http://www.dsec.gov.mo/TimeSeriesDatabase.aspx

Note 2. Statistics Times. (2016). GDP Per Capita Ranking. Retrieved from http://statisticstimes.com/economy/projected-world-gdp-capita-ranking.php

Note 3. The Heritage Foundation (2016). 2016 Index of Economic Freedom. Retrieved from https://www.heritage.org/index/pdf/2016/book/index_2016.pdf

Note $4 . * * *$, and $* * *$ indicate significance at the $10 \%, 5 \%$, and $1 \%$ levels, respectively. 